\title{
Antibody response to central and peripheral nerve antigens in rat and guinea-pig
}

\author{
E. A. CASPARY AND E. J. FIELD \\ From the Medical Research Council Unit on Demyelinating Diseases, The Royal Victoria Infirmary, \\ and the University of Newcastle upon Tyne
}

Experimental allergic encephalomyelitis is readily produced in a number of mammalian species by the injection of brain, or fractions derived therefrom, together with Freund's adjuvant. Whilst substitution of whole peripheral nerve leads to an allergic neuritis, there is considerable species difference in response to these antigens. Thus Waksman and Adams $(1955 ;$ 1956) reported that guinea-pigs developed both central and peripheral lesions after injection with either brain or nerve. In half of those receiving brain, disease was limited to the central nervous system. One-third of guinea pigs challenged with peripheral nerve developed a purely peripheral lesion. On the other hand rabbits did not show central lesions after inoculation with peripheral nerve.

The recent claims by Bornstein and his co-workers (Bornstein and Appel, 1961; Bornstein, 1963) that a specific myelotoxic agent is demonstrable in the blood of acute cases of multiple sclerosis has redirected attention to the antibodies present in this disease and in experimental allergic encephalomyelitis widely regarded as a model for the human condition. Experimental allergic neuritis has been considered similarly related to the Guillain-Barré syndrome and appreciable antibody to nervous tissue found in $50 \%$ of cases (Melnick, 1963). Because of these possible relationships between experimental animal diseases and human conditions it was thought important to investigate the antibody response to both central and peripheral nervous tissue and its products.

A previous immunofluorescent study of antisera prepared against human brain and peripheral nerve indicated that anti-brain serum reacted with both central and peripheral myelin, whilst anti-peripheral nerve serum combined only with peripheral nerve and nerve roots (Field, Ridley, and Caspary, 1963). It was thought of interest to investigate further the circulating antibody response to the active basic protein of central and peripheral origin (Caspary, 1963), especially since a complement-fixing antibody to brain has been claimed effective in protecting against experimental allergic encephalomyelitis (Paterson and Harwin, 1963), and the relative im- portance of humoral factors and cell-fixed antibodies in the pathogenesis of experimental allergic encephalomyelitis remains obscure.

\section{MATERIALS AND METHOD}

White rats (250 g.) and guinea-pigs (Hartley strain 400$500 \mathrm{~g}$.) of both sexes were used in this work. All inoculations (in a volume of $0.1 \mathrm{ml}$.) were made intracutaneously, challenging injections into the dorsum of the right hind foot, whilst preliminary injections were distributed around the other feet. Severity of disease was assessed both on clinical and histological grounds. Haematoxylin and eosin sections from various levels of brain and spinal cord and longitudinal sections of both sciatic nerves were examined.

The brain plus Freund mixture was made up of one part of $20 \% \mathrm{w} / \mathrm{v}$ human white matter and two parts of Freund's complete adjuvant (Difco). The sciatic nerve antigen $(30 \% \mathrm{w} / \mathrm{v})$ was similarly compounded with complete adjuvant.

Encephalitogenic factor, an active basic protein of human brain, was prepared by the method of Caspary (1963) and the same procedure was applied to sciatic nerve in order to obtain a similar basic protein. As a preliminary, sciatic nerve was broken up in a special press (Hughes, 1951) at $-20^{\circ} \mathrm{C}$. resulting in a minimal amount of residual connective tissue strands.

Animal sera were obtained by exsanguination at 30 days or when an animal was moribund and were stored at $-20^{\circ} \mathrm{C}$. before use.

Antibody titrations were carried out by a modification of the tanned red cell technique (Stavitsky, 1954; Field, Caspary and Ball, 1963) using perspex trays ${ }^{1}$ and total fluid volumes of $0.3 \mathrm{ml}$. All sera were inactivated at $56^{\circ} \mathrm{C}$. for 30 minutes and interspecies non-specific 'antibodies' removed by adsorption with an equal volume of washed packed sheep erythrocytes at room temperature. Results were expressed as positive to a number of tubes of doubling dilutions, the first being a one in two dilution.

The following experiments were set up:-

RATS Group A, 26 normal rats; group B, 12 rats inoculated with human brain plus complete adjuvant; group C, 12 rats inoculated with human sciatic nerve plus complete adjuvant.

${ }^{1}$ R. B Turner Ltd. 
GUINEA-PIGS Group D, 29 normal guinea-pigs; group E, 20 animals injected with Freund's complete adjuvant alone; group F, 28 animals injected with brain plus complete adjuvant; group G, 11 animals injected with sciatic nerve plus complete adjuvant; group $\mathrm{H}, 12$ animals injected with sciatic nerve basic protein; group I, eight animals given three preliminary injections of encephalitogenic factor (100 $\mu \mathrm{g}$. in complete Freund's adjuvant) at 10-day intervals followed by challenge 10 days after with brain plus complete adjuvant ; group $\mathrm{J}$, three animals similarly treated with encephalitogenic factor in saline and challenged.

\section{RESULTS}

The results of experiments with rats are set out in Table I, which shows that whilst both experimental allergic encephalomyelitis and neuritis occur in response to brain injection, sciatic nerve results in experimental allergic neuritis in about $50 \%$ of animals accompanied only very occasionally by experimental allergic encephalitis. The table also shows that when either brain or sciatic nerve is injected antibodies against both are produced, but always in higher titre to the latter.

Whilst anti-encephalitogenic factor titre was not significantly different when brain or sciatic nerve was injected (with complete Freund), that against sciatic nerve basic protein was greater following sciatic nerve inoculation. Titres against encephalito- genic factor were raised but not significantly different when either brain or sciatic nerve had been injected (with complete adjuvant). On the other hand, although titres against sciatic nerve basic protein were also raised following either antigenic stimulus, this time there was a markedly greater response to the peripheral antigen (P 0.01-0.001). This applied to both rats and guinea-pigs.

The results of experiments with guinea-pigs are set out in Table II, which shows that brain injection produces experimental alergic encephalomyelitis but little experimental allergic neuritis whilst sciatic nerve inoculation produces the neuritis in some $70 \%$ of guinea pigs but not the encephalomyelitis.

Table II also shows that no statistical significance emerges between anti-encephalitogenic factor levels resulting from brain, sciatic nerve, or sciatic nerve basic protein inoculation $(P=0.3-0.2)$. On the other hand sciatic nerve and its basic protein both produce markedly greater anti-sciatic basic protein response than does brain $(\mathrm{P}<0.001)$. But the internal difference between sciatic nerve and its basic protein falls short of significance $(P=0.4-0.5)$

\section{DISCUSSION}

In guinea-pigs, in which response to adjuvant alone was assessed, neither brain nor whole sciatic nerve

\begin{tabular}{llcccc} 
Group & Treatment & $\begin{array}{c}\text { No. of } \\
\text { Rats }\end{array}$ & $\begin{array}{c}\text { Anti-encephalitogenic } \\
\text { Factor }\end{array}$ & $\begin{array}{c}\text { Experimental } \\
\text { Allergic Encephalomyelitis }\end{array}$ & $\begin{array}{l}\text { Sciatic Nerve } \\
\text { Basic Protein }\end{array}$ \\
\hline A & Normal & 26 & $0 \cdot 4$ & $0 \cdot 3$ \\
Allergic Neuritis
\end{tabular}

${ }^{1}$ Encephalitogenic factor or sciatic nerve basic protein coated tanned red blood cells reacting with antiserum. Results expressed in tubes of doubling dilution.

${ }^{2}$ Not significantly different $(P=0 \cdot 3)$.

'Significantly diffe:ent $(P=0.01-0.001)$.

Numerator $=$ number of animals affected, denominator $=$ number of animals injected.

TABLE II

\begin{tabular}{|c|c|c|c|c|c|c|}
\hline Group & Treatment & $\begin{array}{l}\text { No. of } \\
\text { Guinea- } \\
\text { pigs }\end{array}$ & $\begin{array}{l}\text { Anti-encephalitogenic } \\
\text { Factor }\end{array}$ & $\begin{array}{l}\text { Experimental } \\
\text { Allergic Encephalomyelitis }\end{array}$ & $\begin{array}{l}\text { Anti-sciatic } \\
\text { Nerve } \\
\text { Basic Protein }\end{array}$ & $\begin{array}{l}\text { Experimental } \\
\text { Allergic Neuritis }\end{array}$ \\
\hline $\mathbf{D}$ & Normal & 29 & 0.8 & & $0 \cdot 8$ & \\
\hline $\mathbf{E}$ & Freund's & 20 & $1 \cdot 2$ & & $1 \cdot 0$ & \\
\hline $\mathbf{F}$ & Brain + Freund's adjuvant & 28 & $1 \cdot 5$ & $22 / 28$ & $1 \cdot 8$ & $-^{2}$ \\
\hline $\mathbf{G}$ & Sciatic nerve + & & & & & \\
\hline \multirow{2}{*}{$\mathbf{H}$} & $\begin{array}{l}\text { Freund's adjuvant } \\
\text { Sciatic nerve basic protein }\end{array}$ & 11 & $2 \cdot 5^{3}$ & $0 / 11$ & 6.0 & $8 / 11$ \\
\hline & + Freund's adjuvant & 12 & $1 \cdot 6^{3}$ & $0 / 12$ & $5 \cdot 7$ & $0 / 12$ \\
\hline
\end{tabular}

${ }^{1}$ Encephalitcgenic factor or sciatic nerve basic protein coated red blood cells reacting with antiserum. Results expressed in tubes of doubling dilution.

${ }^{2}$ Not examined in this series; in other similar experiments 1/24 animals examined developed experimental allergic neuritis.

sot significantly different $(P=0.3-0.2)$.

Not significantly different $(P=0.4-0.5)$.

Numerator $=$ number of animals affected, denominator $=$ number of animals injected. 
TABLE III

ANTIBODY RESPONSES IN GUINEA-PIGS PRETREATED WITH ENCEPHALITOGENIC FACTOR ${ }^{1}$

\begin{tabular}{|c|c|c|c|c|c|}
\hline No. & Pretreatment & $\begin{array}{l}\text { Complement-fixation } \\
\text { Test }\end{array}$ & $\begin{array}{l}\text { Encephalitogenic } \\
\text { Factor }\end{array}$ & $\begin{array}{l}\text { Sciatic Nerve } \\
\text { Basic Protein }\end{array}$ & $\begin{array}{l}\text { Experimental } \\
\text { Allergic Encephalomyelitis }\end{array}$ \\
\hline 2037 & Encephalitogenic factor in saline & 1 & 8 & 8 & + \\
\hline 8 & Encephalitogenic factor in saline & 3 & 8 & 0 & + \\
\hline 9 & Encephalitogenic factor in saline & 7 & 8 & 8 & + \\
\hline 2024 & Encephalitogenic factor in incomplete adjuvant & 7 & 8 & 8 & - \\
\hline 5 & Encephalitogenic factor in incomplete adjuvant & 7 & 8 & 8 & - \\
\hline 9 & Encephalitogenic factor in incomplete adjuvant & 7 & 8 & 8 & - \\
\hline 2030 & Encephalitogenic factor in incomplete adjuvant & 6 & 8 & 8 & - \\
\hline 1 & Encephalitogenic factor in incomplete adjuvant & $\mathbf{0}$ & 8 & 8 & - \\
\hline
\end{tabular}

${ }^{2} 100 \mu \mathrm{g}$. On three occasions at 10-day intervals before challenge. Encephalitogenic factor or sciatic nerve basic protein coated tanned red blood cells reacting with antiserum. Complement fixation test using encephalitogenic factor as antigen. Results as tubes of doubling dilution.

nor its basic protein produced titres against encephalitogenic factor different from that against adjuvant alone. Immunization with brain produced similar titres against encephalitogenic factor and sciatic nerve basic protein in the guinea-pig but a greater titre directed against the peripheral nerve basic protein in the rat. Whilst in both species injection of peripheral nerve gave rise to a markedly greater titre against sciatic nerve basic protein antigen than against encephalitogenic factor, the latter titres tended to be rather greater when brain was injected, though not to the point of statistical significance.

These findings correspond with those of Field et al. (1963) in an investigation of the specificity of rabbit antibrain and anti-nerve antibody by immunofluorescence. They showed that anti-brain serum combined with both central and peripheral myelin, whereas anti-nerve antibody reacted only with myelin of peripheral nerve and nerve roots.

Studies of complement-fixing circulating antibody in rabbits following sciatic nerve inoculation by Waksman and Adams (1955) gave essentially equivalent titres against nerve and spinal cord, with a tendency for the latter to be slightly higher. Whole brain was not used in this study. Heitmann and Mannweiler (1957) also injected sciatic nerve into rabbits and reported similar complement-fixing titres to both brain and nerve.

The complement-binding antibody to brain in the rat has been shown to be an S 19 globulin (Harwin and Paterson, 1962) while the tanned cell agglutinating antibodies dealt with in the present work are associated with the smaller $\mathbf{S} 7$ globulins (Caspary and Ball, 1965) so these findings may not be completely contradictory. Paterson and Harwin (1963) have claimed that anti-brain sera of high complement-fixing titre exert a marked suppressive effect on the development of allergic encephalomyelitis. In a series of animals immunized with encephalitogenic factor, protection was only obtained when this antigen was injected with incomplete adjuvant but not in saline (Field and Caspary, 1964). Antibody response, however, both complement-binding and agglutinating, was markedly raised in both cases (Table III). This small series suggests that complement-fixing antibody level (against encephatitogenic factor) is not directly related to protection against experimental allergic encephalomyelitis. Further experiments are being carried out to compare the roles played by complement-fixing antibody in active and passive protection against experimental allergic encephalomyelitis.

Single challenge with brain and adjuvant (in our highly susceptible rats and guinea-pigs) produces central nervous lesions and increased titres to both central and peripheral nervous tissue. Similar challenge with sciatic nerve and adjuvant gives a milder peripheral disease in a number of animals accompanied by a more marked circulating antibody response to the peripheral antigen inoculated and also to brain. The titres in both cases are higher than those evoked by brain. In both experimental allergic encephalomyelitis and the allergic neuritis produced in rats and guinea-pigs no direct relationship could be shown between the antibody titres and the incidence and severity of the disease. This is generally agreed in the case of complement-fixing antibody and the present work shows it to hold good also for agglutinating antibody.

\section{SUMMARY}

In rats a single inoculation of brain in adjuvant leads to both experimental allergic encephalomyelitis and experimental allergic neuritis. A single inoculation of sciatic nerve with adjuvant produces $50 \%$ experimental allergic neuritis but practically no experimental allergic encephalomyelitis. Agglutinating antibody against sciatic nerve basic protein is much greater than against encephalitogenic factor in each case.

In guinea-pigs a single inoculation of brain with adjuvant leads to experimental allergic encephalo- 
myelitis but to no experimental allergic neuritis. Inoculation with whole sciatic nerve leads exclusively to experimental allergic neuritis. Sciatic nerve basic protein produces no disease. Brain produces very little agglutinating antibody to either encephalitogenic factor or sciatic nerve basic protein. Both whole sciatic nerve and sciatic nerve basic protein, however, produce a marked anti-sciatic nerve basic protein response with little anti-encephalitogenic factor.

There is no correlation between pre-existing high complement-fixing or agglutinating antibody to brain and immunity to experimental allergic encephalomyelitis when animals are challenged.

Our thanks are due to Miss Greta Joyce, A.I.M.L.T., for histological assistance and to Miss E. J. Ball, B.Sc., for serological tests.

\section{REFERENCES}

Bornstein, M. B. (1963). A tissue-culture approach to demyelinative disorders. Nat. Cancer Inst. Monogr., No. 11, pp. 197-214.

- , and Appel, S. H. (1961). The application of tissue culture to the study of experimental 'allergic' encephalomyelitis. I. Patterns of demyelination. J. Neuropath. exp. Neurol., 20, 141-157.
Caspary, E. A. (1963). A fraction of high encephalitogenic activity isolated from human brain. Biochem. J., 87, 21-22P.

and Ball, E. J. (1965). Nature (Lond.), in press.

Field, E. J., and Caspary, E. A. (1964). Protective effect of ence phalitogenic factor in experimental allergic encephalomyelitis. Nature (Lond.) 201, 936.

__ _ _ and Ball, E. J. (1963). Some biological properties of highly active encephalitogenic factor isolated from human brain. Lancet, 2, 11-13.

- Ridley, A., and Caspary, E. A. (1963). Specificity of human brain and nerve antibody as shown by immunofluorescence microscopy. Brit. J. exp. Path., 44, 631-634.

Harwin, S. M., and Paterson, P. Y. (1962). Antibrain antibodies of the $19 S \gamma$-globulin type in rats with allergic encephalomyelitis. Nature (Lond.), 194, 391-392.

Heitmann, R., and Mannweiler, K. (1957). Tierexperimentelle Untersuchungen über die 'allergische' Polyneuritis. Dtsch. $Z$. Nervenheilk., 177, 28-47.

Hughes, D. E. (1951). A press for disrupting bacteria and other microorganisms. Brit. J. exp. Path., 32, 97-109.

Melnick, S. C. (1963). Thirty-eight cases of the Guillain-Barré syndrome: an immunological study. Brit. med. J., 1, 368-373.

Paterson, P. Y. and Harwin, S. M. (1963). Suppression of allergic encephalomyelitis in rats by means of antibrain serum. J. exp. Med., 117, 755-774.

Stavitsky, A. B. (1954). Micromethods for the study of proteins and antibodies. II. Specific applications of hemagglutination and hemagglutination-inhibition reactions with tannic acid and protein-treated red blood cells. J. Immunol., 72, 368-375.

Waksman, B. H., and Adams, R. D. (1955). Allergic neuritis: an experimental disease of rabbits induced by the injection of peripheral nervous tissue and adjuvants. J. exp. Med., 102, 213-236.

,$- \quad$ (1956). A comparative study of experimental allergic neuritis in the rabbit, guinea-pig, and mouse. J. Neuropath exp. Neurol., 15, 293-314.

\section{The February 1965 Issue}

\section{THE FEBRUARY 1965 ISSUE CONTAINS THE FOLLOWING PAPERS}

\begin{abstract}
Axon reflexes in human motor nerve fibres PAMELA M.
\end{abstract} FULLERTON and R. W. GILLIATT

Movements induced by straight leg raising in the lumbosacral roots, nerves and plexus, and in the intrapelvic section of the sciatic nerve M. D. GODDARD and J. D. REID

Disturbances of the combustion processes in muscular disorders IRENA NIEBRÓJ-DOBOSZ

Sarcoidosis of the nervous system w. B. MATthEws

Experiences with radioactive gold in the treatment of craniopharyngioma WILLIAM H. BOND, DAVID RICHARDS, and ERIC TURNER

Central pontine myelinolysis in a 7-year-old boy JOHN J. KEPES, CAROL ANN REECE, and DWIGHT $K$. OXLEY

Homolateral ataxia and crural paresis: $A$ vascular

\section{syndrome C. M. FISHER and MONROE COLE}

Polyacrylamide disc electrophoresis of the proteins of cerebrospinal fluid and brain GUY MONSEU and J. $\mathrm{N}$. CUMINGS

Comparison of immunological specificity of gamma globulin in the cerebrospinal fluid in normal and multiple sclerosis subjects E. A. CASPARY

Precise alcoholic Gasserian injection for tic douloureux ARTHUR ECKER and THEODORE PERL

A bilateral cortico-striate projection J. B. CARMAN, W. M. COWAN, T. P. S. POWELL, and K. E. WEBSTER

Physiological and clinical effects of amylobarbitone sodium therapy in patients with anxiety states LORNA WING and M. H. LADER

Book reviews

Copies are still available and may be obtained from the PUBLISHING MANAGER, BRITISH MEDICAL ASSOCIATION, TAVISTOCK SQUARE, W.C.I, price 18s. 6D. 